\title{
AXIOLOGICAL FUNDAMENTS OF RELATIONS BETWEEN ETHICS AND POLITICS*
}

\begin{abstract}
The subject of this article is the axiological basis of relations between morality and politics. The author shows anthropological and metaphysical origins of the idea of common good in social life. What role does morality play in political activity and where are moral foundations of a democratic state to be found? How to ensure the presence of moral values in public life (education, participation, common good, open society). The most important questions include: Who is responsible for ideas of democracy? Can democracy survive without a footing in pre-democratic values?
\end{abstract}

Keywords: democracy; liberalism; common good

1. Introduction. 2. Axiological fundamentals of democracy 3. Liberalism and negation of the idea of common good. 4. Conclusions

\section{INTRODUCTION}

In recent years, philosophical polemics over the axiological status and function of democracy have revived. The debate about moral aspects of democracy leads to at least two radically different positions. The former assumes that the most important issue is a political system that provides civic rights for all people, rather than the state of customs that determines how these rights are used. Democracy has no moral function in terms of social and personal values and goals. It comes down to a formal, purely procedural, legal and institutional

\footnotetext{
* This article was originally published in Polish as: E. Podrez, Aksjologiczne podłoże związków etyki z polityka, Studia Philosophiae Christianae 40(2004)1, 103-121. The translation of the article into English was financed by the Ministry of Science and Higher Education of the Republic of Poland as part of the activities promoting science - Decision No. 676/P-DUN/2019 of 2 April 2019. Translation made by GROY Translations.
} 
status which provides everyone with the same privileges. The use of these privileges remains a matter of individual choice ${ }^{1}$.

This view is challenged by philosophers who, together with democracy, combine the ideals of equality, freedom and respect, subordinated to the dignity of every human being. Thus, the second interpretation refers to a completely different dimension of democracy, seeing it as a constitutive factor. According to this position, values define both the essence of democracy and its basic tasks. An idealistic dimension of this project causes that this system will never be fully implemented. This fact undoubtedly affects the paradoxical nature of democracy. As a multithreaded, historical process, democracy requires constant correction, modification and reform. After all, democracy covers the life of an individual as well as that of the community to the same extent. In this situation, the question of who is to convey these values, ideas and make them generally accepted and desirable models of civic life becomes more important. This imperative cannot be delegated to the law in force in a state, as it is intended to ensure harmonious (i.e. non-conflicting) coexistence for all people. It is based on the acceptance of philosophical, religious and ethical pluralism. The dispute between Socrates and sophists, in which the same themes were discussed, cannot be overlooked here. The way in which these theses were discussed and formulated indicates that morality was treated as a public aspect of human life. It is deeply rooted in a community of language and social experiences. This conviction of the ancients is fully shared by a modern American philosopher, Charles Taylor. "I am rejecting all atomist views; since what man derives from society is not some aid in realizing his good, but the very possibility of being an agent seeking that good"2. Social practice and reflection on its content evoke questions, fears and hopes that lead to the search for the best system for moral de-

1 J. Szacki, Demokracja po komunizmie. Przeciw, a nawet za tezami Krasnodębskiego, Znak 536(2000), 52.

2 C. Taylor, The Nature and Scope of Distributivetive Justice, in: Idem, Philosophy and The Human Sciences. Philosophical Papers, Cambrigde University Press, Cambridge 1985, 292. 
velopment of the citizen. It is traditionally accepted that this system is democracy that binds human values with respect for the dignity of every human being together. These considerations represent the moral superiority of democracy over other political formations, simultaneously, they protect it against external and internal enemies. On the other hand, the same facts determine that democracy is easily subject to all kinds of depravity and banalisation. They are supported by a wave of international conflicts, tensions and threats that undermine the essence of democracy. They are particularly visible from the perspective of the dominance of global and free market economy. The latter introduce radical changes to civilisation, which, among other things, lead to the question of who is responsible for the topicality of democratic ideas, for the realization of its axiological postulates. There is a growing consensus that the fate of democracy should be decided by politicians. Meanwhile, at the root of democracy lies the philosophical interpretation of human nature, its optimal, social and individual development, which is enabled by the principle of justice. This principle guarantees freedom and equality for all citizens as participants of public life. Have these thoughts, ideas, values and concepts lost their meaning today, or are they simply becoming more difficult to implement? Certainly, democracy conceived as an axiological project of life and coexistence between people - demands certain patterns of moral behaviour.

It is therefore worth taking a closer look at why democracy is being severely criticized. Is its theoretical basis being undermined or is its democratic power system being negatively evaluated? Philosophers of old times often stressed that democracy was an elite regime. Only highly civilized countries, where society has reached an appropriate intellectual and moral level, can meet its demands. Therefore, many thinkers point out that most of modern democracies have a genesis which is very diverse in social, economic, historical and cultural terms ${ }^{3}$. Never in history has democracy experienced

3 S. P. Huntington, Zderzenie cywilizacji, transl. H. Jankowska, Warszawskie Wydawnictwo Literackie MUZA, Warszawa 1998, 168. 
such a triumph of popularity, nor has it consistently faced social and economic problems on such a scale as today. In the past, traditional Western democracies emerged evolutionarily through historical processes. In the post-war years, this path was abruptly shortened by revolutions, which entailed social conflicts, economic crises, poverty, debts, unemployment, demoralization and degeneration of marginalized social groups, spreading nationalist demagogy, revival of Nazi ideology, growth of religious fundamentalisms. One can count infinitely the number of plagues which oppress modern societies and which indirectly become a threat to democracy. This also makes that assessment of democracy radically varies; for some communities it is the most "shameful" socio-political formation, which is held responsible for all the negative effects of transformation. For many other communities, democracy remains an unrivaled example of the state's respect for human rights. Usually in such assessments - not free of emotions - the difference between two dimensions of democracy, i.e. the form of governance and the way of life of citizens, is blurred.

Tocqueville, observing democracy in the United States as much as two hundred years ago, drew attention to its internal weaknesses and threats. These certainly include uniformization and promotion of mediocrity, the lack of eminent personalities among politicians, populism, demagogy and the worst evil in the form of politicization of a state. All these disadvantages in some way arise from the same background - mass society. It found many critics, but it seems that it was Ortega y Gasset who portrayed the "spirit" of the mass society most accurately. "A psychological diagram of modern mass man", explains y Gasset, "includes two basic features: a free expansion of demands and needs that life brings, in particular with reference to oneself and a deeply rooted lack of gratitude for those who made this comfortable life possible"4. The lack of gratitude stems from the conviction that all available goods are intended for free consumption. The world of ideals is doomed to negative selection and

4 J. O. y Gasset, Bunt mas, transl. P. Niklewicz, Warszawskie Wydawnictwo Literackie MUZA, Warszawa 1995. 
is increasingly replaced by various value substitutes that are subject to multiple and contradictory interpretations. It also leads to ideologization of democracy, which means that within this reasoning "thought is functionalized, interpreted only in terms of their social, racial, economic or psychological sources and functions" . Detailed research on the conditions of democracy usually does not take the priority of ideas over their historical concretization into account. Indirectly, they lead to ideologization of the foundations of democracy. Democracy is assessed for its side effects, not for its axiological credibility. Reflection on this situation leads to the question whether the axiological fundaments of democracy lies in its public institutions or whether it should be sought in moral culture of society. The first option assumes that integrity, justice, solidarity, etc. are a matter of basic structures of the state, which indirectly oblige citizens to act in a moral way. Another version, in which society and its moral awareness established in tradition ultimately decide about which norms apply in public life, is also adopted.

According to Gasset, "the crux of the matter" lies in the fact that there is no more morality in Europe. This is not about some kind of revolution in the perception of morality as "Nietzschean" revaluation of all values. Gasset speaks of the mass man's natural desire to live beyond morality. This view is shared by many ethicists, political scientists and philosophers. In the light of today's prevailing social attitudes, the absolute acceptance of moral norms is something quite absurd and impractical. Above all, money, status, career, possession, consumption and use, thus all that comes down to "business", are valued. Ethics is not a means of exchange, it therefore does not serve to do business, it refers to objective values of good, beauty and truth. Such patterns of behavior find neither social justification nor political recognition. This shows some elementary flaws in European culture and the concept of education of human being built on it. In the light of these observations, it is worth considering the position of Satori, Taylor or MacIntyre, who unanimously claim that the ideals of democracy have been exhausted, 
only empty phraseology remains. For too many citizens and politicians democracy boils down to unrestricted consumption and "to taking and implementing corporeal politics", comments Kincaid, "that is, to a good life, whose criteria are pleasure and pain". This standard of living has a negative impact on both the state and general public. "It is true that a well-organized society cannot exist without good, where politics is reduced to economics, ideals to ideology and ethics to a calculus"'

The second great threat to democracy to be mentioned is the treatment of egalitarianism as a measure that can be applied to all areas of life. At least two of them do not submit to such criteria - art and science, which by their very nature represent a world of higher, elite values.

As a result, the lack of links between democracy and values, which go beyond pragmatism and egoistic utilitarianism, is increasingly deepening. Undoubtedly, from a certain angle, they confirm the equality and autonomy of an individual, although they undermine the objective status of morality. This negation is not only covered by value judgements, but also their objective grounds. They are reduced to individual beliefs. I have the impression that this fate was not only met by metaphysical or religious rationale, but also the critique of pragmatic rationality. The same degree of relativisation applies to competence, credibility, integrity, as well as a lie, stupidity or betrayal. Under these conditions, pluralism and tolerance only sanction such a state. For some philosophers, these are tolerance and pluralism that determine the moral nature of democracy. However, taking such a position, one immediately falls into the traps set by human nature. As Spaemann rightly stresses: "Persons are and will remain dangerous. ... . Abolition of this state of affairs would mean the elimination of persons and turning people into intelligent animals. That is why we cannot let any theory of the person pass which ignores the possibility of strife or mentions it only to condemn it".

6 J. Kincaid, Resource Scarcity in Western Political Theory: Scare Natural Resources, Beverly Hills 1983, 123.

7 G. Sartori, Teoria demokracji, transl. P. Amsterdamski, D. Grinberg, PWN, Warszawa 1998, 605.

8 R. Spaemann, Osoby. O różnicy między czymś a kimś, transl. J. Merecki, Wydawnictwo 
Undoubtedly, the great value of democracy is its ethos of justice, which is most fully expressed in fundamental human rights. It is difficult to understand them, especially to interpret and indicate a reference, limiting oneself to the analysis of abstract concepts. Therefore, it is necessary to reach into their context, which indicates some area of social and political reality. The democratic approach to human rights translates into a concept of the civil state and an outline of the theory of the common good. An attempt to understand the essence of the relationships between ethics and politics requires a closer analysis of these concepts. It leads to a metaphysical reflection, abandoned today, on a human being and their vocation to do good.

\section{AXIOLOGICAL FUNDAMENTALS OF DEMOCRACY}

The question of whether the ideas of democracy are still valid, or whether they find support in contemporary state structures, is reasonable for all the pathologies mentioned earlier. What attracts the attention of most authors dealing with this issue is expressed in the belief that contemporary democratic societies are experiencing a crisis of their own identity. In view of this state of affairs, such questions become fundamental: Can an ethically divided community maintain political unity? On what foundation should it be based?

Philosophers, who are the authors of already classic studies, proposed three different models of building and recognition of a political community: (1) by identifying the political community with the moral one; (2) assuming that the ethical community is superior to the political one; (3) these communities are secondary in relation to the good and purpose of a human person. These schematic representations clearly show that the concept of community either depends on the status of a state or on the condition of an individual. The arrangements adopted in these considerations make it possible to assess political systems on the basis of the idea of the common good and related category of human good. This picture should be

Oficyna Naukowa, Warszawa 2001, 234, 232. 
complemented by a level of the individual's participation in community activities. Taking a closer look at an individual from the side of participation as well as common good can help to capture the specificity of political existence. Obviously, these issues will only be addressed in this outline in a fragmentary and simplified way.

Many prominent philosophers consider civil society, i.e. a fullfledged axiological community, to be the basis of modern democracies. Equality, freedom and justice are enjoyed by all citizens, but only a few can use them responsibly. Therefore, they choose real citizenship and thus create civil society. It boils down to "historically determined decisions of particular individuals". This community is understood as a "historical product" that is inscribed in particular fates of individuals. The source value for the civic community is an individual: free, aware of their own goals, ready to bear the risk and responsibilities associated with their implementation. In the light of this description, questions arise as to what conditions must (should) exist for people to reach a degree of maturity that will ensure their effective participation in civil society. Philosophers are inclined to treat responsibility as a measure of mature freedom. This is mainly about civic responsibility. Therefore, it is worth recalling that such a responsibility takes three forms. Firstly, we need to refer to its formal aspect, including legal sanctions. Secondly, there is a kind of forced responsibility, e.g. for economic or political reasons. Thirdly, a moral type of responsibility that is voluntary and specifically directed towards good. Every manifestation of moral good has its basis in the personal dignity of human being. That is why people act non solum agentur, sicut alias, sed per se agunt ${ }^{10}$. Individuals therefore act "by themselves" and are free and equal in this sense, i.e. they are particular individuals, not as copies of their species. This dignified context affects the way we understand justice and the autonomy of an individual, and it indirectly indicates the relationship that exists

9 S. Dziamski, Podstawy aksjologiczne demokracji, in: Filozofia a demokracja, eds.

P. J. Juhacz, R. Kozłowski, IF UAM, Poznań 2001, 209.

10 St. Thomas, Summa theologiae, I, 29, 2. 
between the good of a person and the good of community. The category of the common good is deeply rooted in the tradition of philosophical thought, although it does not always meet with acceptance. Its ardent opponents, like its followers, invoke the Aristotelian tradition. This is because of at least two reasons. The first is obvious, Aristotle created a systemic framework for the concept of the common good, linking it to three actors of political life: community of citizens, those in power and a working individual. The second reason for this interest in this thought has its negative aspect. Aristotle's concept is inconsistent, multi-threaded and can be interpreted ambiguously. Aristotle attempts to specify and provide the notion of common good, claiming that a good state is a community of happy life, embracing families and family lines, for the purpose of a perfect and self-sufficient existence. The basis of this good should be seen in virtue, which is developed only in states governed by virtuous rulers, i.e. people who retain reason and generosity in their choices. The common good itself boils down to virtues of the good citizen, which develop and improve in the space of public life. The state is one of primary sources of human upbringing. The basis and purpose of this political paideia become virtues based on prudence and bravery. The best state is where virtues of a citizen are the virtues of a good human being. The realization of the common good, i.e. the concern for moral good of citizens, depends primarily on the arete of those in power. Only the best of them can make decisions for everyone and on their behalf. They should know what is best and most useful to all citizens. Those in power must therefore meet a number of basic conditions to meet challenges of the common good. Some today's liberal-conservative groups refer to them, emphasizing that those who do not have to live by their own work, who have experience in the public sphere and are highly moral people, who are capable of selfless dedication to the state' affairs, should govern a country.

In the above-mentioned postulates, an emphasis is placed on prudence of those in power as their personal arete (bravery, perfection). This is due to the nature of the common good: the common good is treated as a virtue that is primarily exercised by those in power. They 
act as a model of behavior, simultaneously, their decisions form the moral framework of public life. They translate directly into established law. Justice, alongside the good, determines content and meaning of the common good. The external goods available to citizens in a state are limited and, to some extent, always nondurable. They also create a natural space for competition among citizens. On the other hand, inner goods, that is to say, acquired efficiency for prudent, fair and good conduct, serve in a durable way to improve both individuals and community. MacIntyre, referring to Aristotle's practical philosophy, attempts to explain the political function of a virtue in the following way: "A polis needs an arete not only for people to improve themselves internally, but also because, first of all, each country continues, develops in competition with others ..., besides, wise politics is based on prudence, i.e. on the virtue of citizens, leaders and lawmakers, and secondly, power of a state is a function of its life practice, what we call today customs and culture" 11 . The attempt to establish what the common good is in fact, leads to several answers that complement each other. The common good can be understood in several ways, referring to various fragments of Aristotelian Politics: (1) as a virtue that binds together those in power and people that they govern, defined in common as "good citizen and good man"; (2) as a goal, the essence of a state, which is subordinated to what is fair and good for all, given the rational nature of human being; (3) as the sense of a state's action, well-established in "reason" and guided by the "right measure"; (4) the common good as the fundament of the bond between citizens and a state, more specifically, between an individual and community, a community with individuals. In this sense, the common good is the principle of citizens' participation in a state, which is measured by good and justice. The moral law perpetuates this kind of bond.

The notion of common good therefore links the political and moral sphere; both of them belong to the rational activity of human being. In accordance with the Greek tradition, Aristotle is convinced that one cannot separate political wisdom from one's moral attitude. The

11 P. Śpiewak, W stronę dobra wspólnego, Aletheia, Warszawa 1998, 121. 
common good opens up the prospect of civic forms of participation. Contemporary supporters of the common good, despite introduction of significant modifications to this concept, are unanimously in favour of linking political morality with the morality of a state itself. According to these findings, there is a close link between the choice of measures to pursue specific policy objectives and their ideological and political rationale. The fair organization of a state and life of its citizens includes a certain objective whole and unity. Both in terms of facts and ideas. The concept of the common good can therefore be considered to indicate intertwining of relations between morality and politics and vice versa. I do not want to get into the details of these dependencies, but they cannot be identified with each other.

The above-mentioned resolutions should be complemented by two important observations. It was already Aristotle who drew attention to them, emphasizing that there were no perfect political systems, and their advantages and disadvantages carried the stigma of historical experience. Human being always acts under certain conditions, with limited knowledge, which, obviously, has an impact on their moral awareness. New forms of participation emerge in the course of history and affect the realization of the common good in various ways. They take on both creative and pathological nature. This state of affairs at least partly explains the critical comments that some philosophers make about the classical concept of the common good. One should take a closer look at them.

These doubts and criticisms concern both theoretical foundations of the possibility to justify the idea of the collective good and the corresponding concept of a good citizen, i.e. a virtuous man. These issues are discussed from the point of view of contemporary state organizations and lead to fundamental changes in the way we understand the concept of common good. Oakeshott clearly states that the instrumental vision of politics within the theory of the common good is contrary to the individualistic one, i.e. libertarian tradition of Europe ${ }^{12}$. Hence, he calls for rethinking of the basis of the rela-

12 M. Oakeshott, On human Conduct, Clarendon Press, Oxford 1975, 19-23. 
tionship between an individual and community; what should it be based on? The discussion, or rather dispute, that is currently taking place between communitarists and liberals concerns this very issue. However, the importance of this dispute has a much broader context for ethics and politics. It can be considered on three levels: (1) historical level - it is about confronting two distinct ways of interpreting the essence of the relationship that exists between an individual, society and a state; whether they are based on constant characteristics of human nature or have their roots in progress, civilization; (2) they refer to the fundamental question of state's tasks; is the state to create the common good or to protect the inalienable rights of individuals (freedom, equality, autonomy and the right to property); (3) they are an attempt to answer the question whether moral truths can become political principles and how they can be legitimized. Is the state to open up the widest field of freedom to citizens and all of them will enjoy this right according to their abilities, or should the state take on the role of a teacher and educator?

\section{LIBERALISM AND NEGATION OF THE IDEA OF COMMON GOOD}

Any answer to such wide-ranging questions concerning moral tasks facing the state must relate to changes in the way values are perceived and hierarchized. While defending a certain concept of a state based on the idea of the common good, one should remember about the relative nature of things of value and human attitudes related to their realization. The idea of the common good includes a diverse world of values, corresponding to many spheres of human activity. For this reason, the problem does not lie in the question of what this idea serves, i.e. whether the moral improvement of a person or the improvement of living conditions, but whether there is an overriding value that links them together. The resolutions to these issues, found in the literature, lead to the separation of two positions: those developed by liberal and communitarist thought. The former is represented by Rawls, who assumes that "everyone is equally free to carry out any life plan according to their own discretion, as long as it 
does not violate the principles of justice"13. In this above-mentioned dispute, Rawls takes a liberal stance. On the other hand, the communitarists, including Alsaider MacIntyre, Charles Taylor, Michael Sandel and Michael Walzer, advocate a vision of man who realizes himself by means of socially rooted goods and values. The concept of the human as a social being by its nature entails the conviction that dignity - as a measure of human moral value - can only be realized in the society. The conclusions that follow from the above-mentioned assumptions lead, on the one hand, to the rejection of the liberal model of society, i.e. of so-called atomist views. On the other hand, they lead to the recognition of natural, primordial relationships of an individual with society. They are in stark contrast to the views developed by liberals, who treat the individual (not social) aspect of human life as a measure of individual self-fulfillment. Looking for axiological fundaments of democracy, a closer look at the essence of this conflict is needed.

The first problem, which is indicated by the cited dispute, concerns the form of social existence and its (non-)involvement in shaping an individual's morality. Sandel describes the essence of this problem in more detail, explaining that for communitarists the community is a factor that constitutes the moral identity of man. Taylor's works not only develop this idea, but also attempt to confront it with the achievements of European philosophy and culture. For this philosopher, social space combines language, tradition and communication as the fundament of human existence. While liberals refer to institutions to protect the freedom of citizens, communitarists demand the establishment of additional institutions to give moral meaning to this freedom. MacIntyre's stance on the social significance of moral discourse is characteristic of this trend. It only makes sense if it is based on some concept of human purpose. Thanks to this, the history of human life is filled with values, virtues and patterns that are socially recognized and practiced. They draw

13 A. Szahaj, Jednostka czy wspólnota? Spór liberałów z komunitarystami a "sprawa polska", Aletheia, Warszawa 2000, 14. 
their intersubjective nature from it too. "The history of my life ... has always been integrated within the history of those communities from which I derive my personal identity..... Historical identity and social identity overlap" 14 .

The dispute in question specifically concerns the content and form of the community bond, its axiological background. The reflection on these issues and their interpretation is connected with the choice of some philosophical heuristics. Can communities be created or discovered based on moral or anthropological laws? "Should we", A. Shahaj adds, "start with some idea of good accepted in advance and from its perspective look at individuals, evaluate their actions ... or rather vice versa: should we start with individuals and, by virtue of their conscious support and consent, move on to defining the common good, as the liberals demand?" 15 .

Therefore, the question is: is there a single, traditionally established moral model of good life and good society? In one of his works, Philips $^{16}$ investigated that issue thoroughly, taking the ideal of community formulated by communitarists as a starting point. The results of his arduous historical and sociological studies can be presented in several points: (1) human mobility in every historical period shows that people did not always accept their membership in a given community; (2) people in every community differed from each other, which was manifested, among other things, by a different attitude to traditions, values, goals and inherited patterns of behavior; in other words, community is the foundation of many narratives and many separate histories; (3) in each community there were conflicts, rivalries, differences in interest, and differences in treatment of other people; (4) social solidarity in such communities was also limited and selective.

This reminder of "hard facts" allows us to discover one more level of dispute. It is about the interpretation of European tradition,

14 A. Maclntyre, Dziedzictwo cnoty, transl. A. Chmielewski, PWN, Warszawa 1996, 394.

15 A. Szahaj, Jednostka czy wspólnota? Spór liberałów z komunitarystami a "sprawa polska", op. cit., 157.

16 See: D. L. Philips, Looking Backward. A Critical Appraisal of Communitarian Thought, Princeton University Press, Princeton 1993. 
taking its links with moral philosophy into account. The communitarianists refer to the heritage of Aristotle's, St. Thomas' and Hegel's thought. The Liberals reach for texts by Locke, Mill and Kant ${ }^{17}$. Apart from the historical dimension of these connections, they indicate different ways of approaching morality and its functions; whether its sources should be sought in permanent, unchanging principles, goods and goals, or whether morality is shaped by changing historical processes.

In order to fully outline this issue, one more question needs to be posed: does liberalism remain neutral to values and the common good? The communitarists accuse the liberals of being in favour of individualism, autonomy, subjectivity and egoism. Marcel Weissenberg distinguished two ideal liberal types ${ }^{18}$, which he described as rational egoism and enlightened individualism. According to this description, a liberal individual feels responsible only for their own interests without adopting any social obligations. A liberal state is programmed not to advocate any system of values, which does not mean that it does not take certain moral assumptions. Axiological neutrality, which has been accepted by a liberal state, is a form of acceptance of civil liberties. This very fact is assessed differently by both critics and supporters of liberalism. MacIntyre maintains the view that "the overriding good of liberalism is ... constant maintenance of the political liberal order. Thus liberalism originally rejecting any overriding theory of good in fact began to embody such a theory" ${ }^{19}$. Gray, on the other hand, points out that we have to give up universalistic models because they are simply inadequate to the current conditions of life and its development. According to this author, liberalism expresses its realism by opting for pluralism of values. This position does not stem from worldviews, but refers

17 Cf. Liberalizm u schyłku XX wieku, ed. J. Miklaszewska, Meritum, Kraków 1999; also: M. Król, Liberalizm strachu czy liberalizm odwagi, Znak, Kraków 1996.

18 M. Wissenburg, Liberalna osobowość, transl. A. Pawelec, in: Demokracja w Europie Środkowej, ed. J. Miklaszewska, Instytut Studiów Strategicznych, Kraków 2001, 228.

19 As cited in: A. Szahaj, Jednostka czy wspólnota? Spór liberałów z komunitarystami a "sprawa polska", op. cit., 26, note 34. 
to cultural differences in contemporary societies. "For us, the postmodern condition of divided perspectives and not well-established practices is a historical fate, we should be wise enough to take the best from it. Secondly, we should consider communities, rather than individuals, as persons of political life. Thirdly, instead of considering the pluralism of individual lifestyles ... we should consider the pluralism of entire life forms. Fourthly, Western liberalism should be considered as being associated with a certain form of community. Fifthly, agonistic liberalism, emphasizing the impossibility of finding a common measure for different values ... contributing to the understanding of politics as the political art of achieving modus vivendi ..., as the pursuit of peace, not truth ..." ${ }^{20}$. These claims should be considered against a broader, theoretical background. In all its theoretical versions, liberalism is characterized by: (1) axiological neutrality, so that freedom ensures equality for all; (2) adopting a certain version of the ethics of liberalism, in which the principle of justice and individual virtues play a major role; (3) liberalism postulates a certain model community based on the ideal of righteousness and a full dimension of humanity.

Liberalism does not so much reject values as it situates them within individual attitudes, without referring them to the metaphysical roots of existence. Therefore, there is acceptance of moral pluralism in practice, not in the world of theoretical ideas.

In the light of these recent remarks, it is worthwhile to raise the issue of the attitude of liberalism towards the common good once again. Contemporary authors point to two formal dimensions of the common good: legal and procedural. The law of the community determines its good and defines it in relation to collective life. The procedural dimension, on the other hand, refers to the social fact that there is a practical agreement on the scope of elementary needs. None of these dimensions of the common good dictates what people should do to achieve full development. For liberals, the greatest

20 J. Gray, Enlightemment's Wake. Politics and Culture at the Close of Modern Age, Routledge, London 1990, 123. 
political crime is to deprive people of their freedom of choice and the right to their own beliefs. This is an act equivalent to depriving them of their elementary dignity. What remains, then, is acceptance of the fact that "We are ... doomed to accept the constant presence of certain uncertainty, dispersion, separation of powers and polytheism ... in our lives"21. Thus liberalism questions the axiological sensibility of public life for an individual. A moral dimension of the common good is denied, only current legal and procedural aspects remain. This state of affairs is confirmed by the liberal tendency to defend autonomy of the person against the community and to affirm individualism and dominance of values of private life. These assumptions take on a different meaning today than in the 19th century. They concern a mass society subject to market pressure and a dominant consumer attitude. Since then, the structure and organization of the state, as well as economic, social, cultural and religious conditions, have changed radically. In many areas of life, two simultaneous processes are currently taking place: disintegration of the community and atomization of civic life; yet it is the neoliberalist trend that maintains the belief that the obvious consequence of economic growth is an increase in welfare of all citizens, which will undoubtedly make them happy. It is not difficult to note that utilitarian roots are behind such views. They undermine both a democratic framework of the state and the common good. This is due to the obvious fact that utilitarianism cannot be reconciled with the idea of democracy. The disputed issue does not only concern the conflict between moral criteria of what is good and right and an utilitarian measure of political effectiveness. In fact, it is about how the value of social life is understood - whether it is limited to the exchange of benefits or whether it is a field of cooperation and interaction between people. Every such dispute refers to the concept of human being from the perspective of dynamic changes in civilization. If this interpretation closes within the framework of naturalism and

21 A. Szahaj, Jednostka czy wspólnota? Spór liberałów z komunitarystami a "sprawa polska", op. cit., 270. 
practicism, the utilitarian model of life will prove to be the most appropriate for it - both with regards to an individual and community. This field of research can be extended if the metaphysical level of reflection on human and their nature is also taken into account. We then reach fundamental questions that transcend the limits of what is historically finite and empirically documented. This metaphysical reflection, not free from tensions and internal dialectics, refers to the intellectual and spiritual dimension of human existence. From this perspective, it is clear that democratic ideas have their origin in philosophical meditation on the vocation of human being. "Each thought", writes B. Skarga, "carries an axiological charge from which no one can free themselves. Contrary to all attempts, it is impossible to separate thought from paideia" 22 . In the project of democracy, which has already been mentioned before, the idea of educating people is inscribed in the circle of tradition, language, values and social communication. Dialectics of thinking leads to the emergence of various theories, practice allows to confront them with reality. Thus it is possible to extend the criteria for lifestyle choices as well as forms of participation. This creative, human attitude is born out of the awareness that every social reality shows some axiological deficiencies, so it demands changes, modifications and reforms. The fulfillment of man and community in the world of values is expressed in the desire aptly formulated by Ricoeur that humanity would be one and each individual would develop individually. This postulate clearly indicates the teleological and perfectionist nature of the common good. It reveals a goal and helps to achieve it fully. This is also what the idealistic spirit of democracy is - if it is reduced to the sphere of "facts", the balance between the stability of the state, the principle of justice, and the dignity and freedom of citizens will be undermined. Moral ideals, such as perfection, fullness and unity, cannot be reduced to political imperatives. Exceeding the measure of reason is always dangerous both for an individual and community. Hence, the emphasis in democracy is put on active participa-

22 B. Skarga, Ślad i obecność, PWN, Warszawa 2002, 134. 
tion of citizens, i.e. various forms of cooperation and collaboration with other people in the pursuit of the common good. These forms are becoming more and more complex and require from citizens not only lifelong learning (i.e. acquisition of knowledge), but also self-education. Above all, it involves the realization of one's own humanity, in which respect for others, manifesting itself in love, justice, nobility, honesty and credibility, is inscribed. Not only the good of a person, but also social order is based on these values. In this order, an individual should find not only support for their efforts, but also certain patterns, established in tradition and social customs.

\section{CONCLUSIONS}

At the end of this brief essay, I would like to return to the question asked in the Introduction: who is to convey values and the world of democratic ideas, to make them universally recognized and desirable models of civil life? This issue has already been raised in dramatic circumstances and referred to the philosopher's social mission. Socrates confesses that "... like a gadfly released by the hand of a god who by stinging rouses the Athenian horse out of its slumber. ... I, who keep waking you up and annoying you ..." ${ }^{23}$. The path that Socrates pointed out runs in the public space of a discourse about what is fair, right and good. The philosopher's task is to provoke such a social dialogue, to ask questions that are essential for an individual and community, force self-reflection, reach for what is always a value. The Socratic discussion about justice and other virtues “... restores the possibility of an expression in which a person, abandoning reciprocal relationships, appears as the only one, unique"24. I will use B. Skarga comment to complement Levinas's thought "These meetings face to face abolish anonymity, thus attributing responsibility to me. Even for this reason, it is difficult to consider it an epi-

23 Platon, Obrona Sokratesa, transl. W. Witwicki, PWN, Warszawa 1958, 113.

24 E. Levinas, Całość i nieskończoność. Esej o zewnętrzności, transl. M. Kowalska, PWN, Warszawa 1994, 358. 
sode of personal life; on the contrary, we can assume that the sources of community and culture are hidden in it" 25 .

I should conclude my considerations here. What is most important in them is focused in the area of relations linking the idea of the common good with the presence of a metaphysical reflection on the meaning of human existence. On the other hand, a culture of thinking affects specific human activity and, more broadly, social models of democratic education. Without strong axiological fundaments, this process must lead to degradation and atomisation of social life. These issues cannot be resolved through political compromises or social negotiations alone.

\section{BIBLIOGRAPHY}

Dziamski S., Podstawy aksjologiczne demokracji, in: Filozofia a demokracja, eds. P. J. Juhacz, R. Kozłowski, IF UAM, Poznań 2001.

Gasset J. O. y, Bunt mas, transl. P. Niklewicz, Warszawskie Wydawnictwo Literackie MUZA, Warszawa 1995.

Gray J., Enlightemment's Wake. Politics and Culture at the Close of Modern Age, Routledge, London 1990.

Huntington S. P., Zderzenie cywilizacji, transl. H. Jankowska, Warszawskie Wydawnictwo Literackie MUZA, Warszawa 1998.

Kincaid J., Resource Scarcity in Western Political Theory: Scare Natural Resources, Beverly Hills 1983.

Król M., Liberalizm strachu czy liberalizm odwagi, Znak, Kraków 1996.

Levinas E., Catość i nieskończoność. Esej o zewnętrzności, transl. M. Kowalska, PWN, Warszawa 1994.

Liberalizm u schytku XX wieku, ed. J. Miklaszewska, Meritum, Kraków 1999

MacIntyre A., Dziedzictwo cnoty, transl. A. Chmielewski, PWN, Warszawa 1996. Oakeshott M., On human Conduct, Clarendon Press, Oxford 1975.

Philips D. L., Looking Backward. A Critical Appraisal of Communitarian Thought, Princeton University Press, Princeton 1993.

Platon, Obrona Sokratesa, transl. W. Witwicki, PWN, Warszawa 1958.

25 B. Skarga, Ślad i obecność, op. cit., 72. 
Sartori G., Teoria demokracji, transl. P. Amsterdamski, D. Grinberg, PWN, Warszawa 1998.

Skarga B., Ślad i obecność, PWN, Warszawa 2002.

Spaemann R., Osoby. O różnicy między czymś a kimś, transl. J. Merecki, Wydawnictwo Oficyna Naukowa, Warszawa 2001.

Szacki J., Demokracja po komunizmie. Przeciw, a nawet za tezami Krasnodębskiego, Znak 536(2000), 43-53.

Szahaj A., Jednostka czy wspólnota? Spór liberatów z komunitarystami a "sprawa polska", Aletheia, Warszawa 2000.

Śpiewak P., W stronę dobra wspólnego, Aletheia, Warszawa 1998.

Taylor C., The Nature and Scope of Distributivetive Justice, in: Idem, Philosophy and The Human Sciences. Philosophical Papers, Cambrigde University Press, Cambridge 1985.

Wissenburg M., Liberalna osobowość, transl. A. Pawelec, in: Demokracja w Europie Srodkowej, ed.J. Miklaszewska, Instytut Studiów Strategicznych, Kraków 2001.

\section{Ewa Podrez}

Cardinal Stefan Wyszyński University in Warsaw, Institute of Philosophy, Poland ORCID: https://orcid.org/0000-0001-5805-0869

e.podrez@uksw.edu.pl

DOI: 10.21697/spch.2020.56.S2.11 